International Journal of Business Management, Entrepreneurship and Innovation, Volume 2, Issue 2, 2020, PP 1-18, ISSN 2707-8027

ilJCAB

\title{
Employee Characteristics, Contemporary Human Resource Management Practices and Organization Effectiveness
}

\section{Florence Adhiambo Adero', Wilson Osito Odiyo}

${ }^{1}$ Pan Africa Christian University, School of Post Graduate Studies, Leadership Department, Nairobi, Kenya, contacts: Email florence.adero@students.pacuniversity.ac.ke, Mobile +254722671441

${ }^{2}$ Pan Africa Christian University, School of Post Graduate Studies, Leadership Department, Nairobi, Kenya, contacts: Email wilson.odiyo@pacuniversity.ac.ke, Mobile +254722605269

\section{ABSTRACT}

The purpose of this paper is to review existing literature on employee characteristics, contemporary human resource management practices and organization effectiveness. A framework was then developed that can be used by future leaders to make organizations more effective. This paper used a literature review of journals on employee characteristics, human resource management practices and organization effectiveness. The purpose of this review was to collect and summarize empirical evidence from literature that fits within the context of this study. Organization leaders face the unsurmountable task of achieving organization effectiveness using the limited resources at their disposal. From the literature review findings, organization effectiveness is achievable so long as the management recruits employees with the desirable characteristics, puts into place contemporary human resource management practices to manage the employees. This will help the organization to achieve its goals, acquire resources and satisfy stakeholders.

Key Words: Organization Effectiveness, Employee Characteristics, Human Resources Management

DOI: $10.35942 / j b m e d . v 2 i 2.111$

\section{Cite this Article:}

Adero, F., \& Odiyo, W. (2020). Employee Characteristics, Contemporary Human Resource Management Practices and Organization Effectiveness. International Journal of Business Management, Entrepreneurship and Innovation, 2(2), 1-18. https://doi.org/10.35942/jbmed.v2i2.111

\section{Introduction}

The unique competitive advantage that successful organizations enjoy lies in the unique characteristics of their employees and the varied human resource management practices that are in place (Hamadamin and Atan, 2019). As aptly put by Tahsildari and Shahnaei (2015) "in this era characterized by rapid and continuous change, knowledge capital must be retained in order for organizations to be responsive and productive to the needs of their stakeholders" (p.56). This can only be achieved if organizations proactively engage in the activities of attracting and retaining highly skilled, adaptive and emotionally intelligent employees. These activities are embodied in the human resource management practices. According to Osborne and Hammoud (2016) an organization's effectiveness is determined by the level of effort and input of each employee. However, employee characteristics affect organization productivity. This has mandated organizational leaders to monitor how the diverse and unique employee characteristics can be used to enhance organizational effectiveness. 
International Journal of Business Management, Entrepreneurship and Innovation, Volume 2, Issue 2, 2020, PP 1-18, ISSN 2707-8027

\section{[IJCAB}

Kanwal et al (2017), assert that "effective organizations should focus on human resources and also help the individuals to gain self-confidence and skills to adjust themselves in the environment" (p.29). Inevitably, and especially at the managerial level, the organization may have to be adjusted to fit the particular strengths and attributes of people available. For any organization to be effective, it needs a talented, dedicated, knowledgeable and motivated workforce (Alami et al, 2015). In this workforce, some people must perform leadership roles, whereas others must be the followers. Organizations have systems of authority, status, power and people in organizations perform their assigned roles in the context of these systems. These systems are the embodiment of human resource management practices (Meraku, 2017).

According to Sherman et al (2015) to manage people effectively, it is necessary to take into account the factors that affect how they behave at work. This means understanding the significance of the personalities of people. According to Nuckcheddy (2018) employee personality has a significant impact on the work environment. It is interesting to note that "where management fails to organize compatible personalities into departments, groups, and teams, the likely result is that conflicts will occur (Nuckcheddy, 2018 p. 3). Sherman et al (2015) reinforce that when employees with personalities that can complement each other are put in one team, the end result is harmony and constructive deliberations with minimal conflict. Such employees can help an organization to gain competitive advantage in its industry of operation because of their ability to use their unique personalities and differences to achieve organizational effectiveness (Arati, 2017). According to Nzuve and Njambi (2015) it is important for the organization leadership to know the employee attitude towards management practices. Some of the human resource management practices that influence employee attitude are; remuneration, promotion, work-life balance, and the influence of the group that they identify with. The knowledge of employee attitude is critical for the development and implementation of HR practices in the organization as they also influence employee characteristics in the workplace (Armstrong \& Brown, 2019).

Organizations face challenges as they operate in a dynamic and highly competitive environment. Improving organization effectiveness is a key concern for any organization as a matter of existence. As aptly put by Tahsildari and Shahnaei (2015) "enhancing organizational effectiveness is the key for success in any business and consequently managers are expected to increase the efficiency of their work environment" (p.56). Rahmawati et al (2016) argue that organization effectiveness entails fostering and retaining a highly skilled workforce and having reliable employees who are willing to work and carry out the assigned tasks to the best of their ability. In addition to this, the employees should be spontaneous and highly adaptive as they perform their roles in the organization. Bashaer and Singh (2016) contend that organization effectiveness depends on the employee characteristics because character quality is what determines an employee's ability to lead others, overcome obstacles, uphold ethical behavior and find better ways of performing assigned tasks. It is clear that organization effectiveness cannot be maintained without having the right HR practices in place (Tahsildari \& Shahnaei, 2015).

Waheed et al (2018) asserts that contemporary HRM practices are valuable and significant for organization effectiveness. However, Atristain-Suarez (2016) caution that theorists recommend specific bundles of HRM practices. Modern organizations are facing challenges because they must put into place bundles of HRM practices that are flexible and can help the organization to adapt to the rapid and complex changes in the environment. According to Schuler and Jackson (2014) an organization's HRM practices should be designed and grounded on the comprehensive understanding of specific employee behaviours that can lead to organization effectiveness. 
International Journal of Business Management, Entrepreneurship and Innovation, Volume 2, Issue 2, 2020, PP 1-18, ISSN 2707-8027

[IJCAB

However, the internal and external environment of organizations makes aligning HRM practices to employee behaviour very complex. This is because the organization leaders have to balance the interests of employees, stakeholders, supply chain partners, partner organizations and clients (Mondy \& Martocchio, 2016).

\section{Literature Review}

\subsection{Employee Characteristics}

Hirasawa (2016) observes that in Japan, employers prefer to hire fresh university graduates as opposed to seasoned employees with a lot of experience. This is because a lot of emphasis is attached to character rather than professional experience. Interestingly, character is seen as an individual's driving force for growth and development and employers firmly believe that skills can be learnt on the job as the new recruits work alongside their workmates. An individual's character is the avenue through which he or she expresses values and is what brings out the much needed strengths of leadership, adaptability, achievement, positive attitude and emotional intelligence. (Boe and Bang, 2017). Armstrong (2009) sets forth some of the personal characteristics that influence employee behavior at work are; emotional intelligence, personality, ability, attitude and intelligence.

\subsection{Emotional Intelligence}

Kannaih and Shanthi (2015) define emotional intelligence as an individual's ability to perceive and control his or her emotions in relation to the environment. In the work context, an emotionally intelligent person can identify, understand, regulate and use his or her emotions to manage the complex issues as they emerge. Drigas and Papoutsi (2019) assert that employees operate in hyperturbulent contexts where they face intense competition, a mass influx of information and new technologies. In the midst of all these, employees need to steer their organizations to success under the umbrella of continuous learning, robust interpersonal relationships and teamwork. Higgs and Dulwicz (2016) advises that employees with emotional intelligence are better at managing relationships and are high performers by the power of their emotions. For example, Tripathy (2018) states that employees who manage emotionally are a great asset to an organization as they can adhere to unwritten rules and are able to interact cooperatively in the interest of enhancing organization effectiveness. In addition to this, they inspire, understand and recognize each other's needs and feelings. They also have the maturity to minimize interpersonal conflicts that may impede organization effectiveness.

\subsection{Personality}

Nuckcheddy (2018) defines personality as the total sum of a person's characteristics that distinguishes them from other people. This is what forms the unique differences among organization members. Youshan and Hassan (2015) on the other hand defines personality "as the individual's characteristics and behavior organized in such a way that reflects the unique adjustment that the person makes to his or her environment" (p.188). It is an individual's habitual way of thinking, feeling, perceiving and reacting to the world and his or her organization. Najamus-Sahar (2016) has clearly set forth the big five factor model that expounds on the five personality traits. At the top of the list is; neuroticism, extraversion, openness to experience, agreeableness and conscientiousness. These traits describe the most salient aspects of personality. Youshan and Hassan (2015) reinforce that personality traits have been shown to have an impact on workplace 
International Journal of Business Management, Entrepreneurship and Innovation, Volume 2, Issue 2, 2020, PP 1-18, ISSN 2707-8027

\section{[ICAB}

behaviors, attitudes and performance and are linked to commitment, burnout, knowledge sharing and motivation.

According to Cross and Carbery (2016) an employee who embodies openness to experience as a personality trait is very useful to the organization. This is because such an employee relates to intellect, openness to new ideas, cultural interests, educational aptitude and creativity. An employee who is open to new ideas is a great asset to an organization because in the event of change, he or she easily adapts to change. An educational aptitude means that such an employee is open to learning new work processes if and when needed. Siddiqi (2016) agrees with this assertion and adds that an employee with this personality trait can enhance organization effectiveness especially if given room to be creative. However, he or she must be appraised from time to time to provide feedback on performance goals.

\subsection{Ability}

Manik and Sirdhata (2017) define ability as the quality possessed by people that makes action possible. There are spatial abilities that cover the areas of perceptual speed, numerical ability, verbal meaning, memory, verbal fluency and inductive reasoning. Other aspects of ability are cognitive, intellectual, verbal and motor skills. Park and Park (2019) confirm that in the work context, ability is the competence of employees and their level of suitability for their assigned roles and responsibilities. McShane and Gilnow (2018) reveal that each individual has abilities that make them superior to their workmates in performing assigned tasks. According to Pradhan and Jena (2017) after performing a task repeatedly, an employee enhances his or her ability to acclimatize to the job profile even when faced with unreasonable deadlines. Park and Park (2019) adds that this also enables the employee to deal with technological advances, organization restructuring and changes in the core work processes. From the above assertions by the different authors, an employee's adaptive ability is the metaphorical engine that runs employee performance and feeds into organization effectiveness.

\subsection{Attitude}

D'Souza and Poojary (2017) define attitude as "a psychological tendency that is expressed by evaluating a particular entity with some degree of favor or disfavor" (p. 2). In the organization context, some attitudes found in employees facilitate workflows and processes while some employees whose psychological orientation is negative will hinder the achievement of organizational goals. Subramanian (2016) advises that negative employee attitude can demoralize work teams and should be curtailed by identifying escalating attitude problems in a timely manner so as to turnaround potentially harmful situations in the workplace. Employee attitude problems may emanate from the work place or from their domestic set-up. Regardless of the source of the employee attitude problem, the sum total impact of the employee attitude on organization effectiveness cannot be ignored (Inuwa, 2015).

According to Rahman and Kodikal (2017) organization effectiveness is achieved if employees are happy and content with their job roles. This can only happen if employees have a positive attitude towards their jobs. Beardwell and Thompson (2017) adds that it is imperative for organization leaders to identify the HR practices that have a positive impact on employee attitude. Employee job satisfaction can influence his or her attitude towards the organization and the performance of the assigned roles. Sharma and Dhar (2016) confirm that past studies have revealed that organizations where sales staff have favorable attitudes towards the organization enjoy high 
International Journal of Business Management, Entrepreneurship and Innovation, Volume 2, Issue 2, 2020, PP 1-18, ISSN 2707-8027

\section{IJCAB}

profits. As espoused by the above authors, a manager should proactively evaluate employee attitude as this influences employee performance.

\subsection{Intelligence}

Marwaha (2015) defines intelligence as an individual's mental capacity to attain, employ and handle knowledge. An intelligent employee is able to effectively think, recall, learn, understand and analyze the logical problems in the workplace. Mahmood et al (2015) adds that an intelligent employee is an asset to an organization as he or she is able to solve problems and implement what was learnt leading to organization effectiveness. However, Heath et al (2017) caution that intelligent employees make decisions in a hierarchical manner but may not effectively build a team or excel in customer service. They contend that an intelligent employee has to be emotionally intelligent so as to contribute to organization effectiveness. According to Leutner and ChamorroPremuzic (2018) most organizations are grappling with the challenges of harnessing the full potential of employees due to their inability to focus on the intelligent individuals. This can be corrected by focusing on an intelligent employee whose output can be increased through training that adds value to his or her abilities. As a human resource management practice, organization leaders should integrate the enhancement of employee intelligence to help employees accomplish their work goals. In addition to this, it will enhance the full utilization of the potentials of employees (Abubakar et al, 2015).

\subsection{Human Resource Management Practices}

Atristain-Suarez (2016) defines human resource management practices as key activities that are designed, implemented and interpreted in accordance with the organization context. Ong et al (2019) have set forth some of the critical HR management practices. These are; recruitment and selection processes that are geared towards selecting flexible and highly committed individuals, supervisory support, organization design, performance management, high spending on training and managing the employment relationship. However, Waheed et al (2019) argue that "organizations must adopt new and innovative HR practices that are flexible and can adopt the possible changes of the organization climate" (p. 2). There are some contemporary HR practices that are valuable and significant in terms of relevance. These are; diversity management, strategic human resource management, talent management, psychological contract, coaching and adaptive performance (Beardwell \& Thompson, 2017).

\subsection{Diversity management}

Barak (2017) defines diversity as a group characteristic that shows the extent to which there are differences in a group. There may be instances when diversity is perceived and is not real. Triana (2017) states the team members can be diverse on the attributes of "sex, race, age, personality traits, attitudes, values, religion, skin color, education, sexual orientation and organizational tenure" (p.3). A diversified workforce is an asset to an organization because it can help an organization to get real time perspectives on global environments in terms of culture and competition. This can also help an organization to gain competitive advantage as it penetrates foreign markets (Triana, 2017). Team diversity can help a team to arrive at creative work solutions in comparison to a homogenous team. This is particularly useful when the task at hand is complicated. Having diversified knowledge and perspectives plays a role in enhancing the alternatives presented and high quality decision making (Kirton \& Greene, 2016). 
International Journal of Business Management, Entrepreneurship and Innovation, Volume 2, Issue 2, 2020, PP 1-18, ISSN 2707-8027

[IJCAB

However, Triana (2017) states that global leaders face the daunting task of managing diversity. This is compounded by the fact that homogenous societies have become heterogenous due to globalization, technological advances and the emergence of borderless organizations. Barak (2017) appreciates the complexity of diversity and states that "the problems of managing today's diverse workforce do not stem from the heterogeneity of the workforce itself but from the unfortunate inability of corporate managers to fully comprehend its dynamics, divest themselves of their personal prejudicial attitudes, and creatively unleash the potential embedded in a multicultural workforce" (p. 26).

According to Fapohunda (2016) embracing diversity as an HR practice involves taking full advantage of workforce diversity and this can help an organization to save costs on recruitment, employee training, access to a wider pool of candidates in the global labor market and increased flexibility in hiring practices. However, Kirton and Greene (2016) differs with this assertion and cautions that "merely having a diverse workforce will not necessarily improve production if employees do not feel valued" p. 233). Triana (2017) adds that there are organizations that recruit employees from developing countries because they can pay them lower wages and save labor costs. Fapohunda (2016) advises that as an HR practice, an organization that has embraced diversity should have proactive policies that initiate equal rights and benefits for all employees, permit specialized treatment for blind employees by acquiring braille keyboards and build ramps to facilitate the movement of disabled employees (Kirton \& Greene, 2016).

\subsection{Strategic Human Resource Management}

Hamadamin and Atan (2019) assert that human resources are an organization's most important asset. This is an old adage that has been echoed by several theorists and authors in the field of human resource management. Strategic human resource management is the deliberate and planned use of human resources to achieve organizational objectives. Organization leaders have to work proactively to combine other organization resources, structures and processes with the human resources to influence its performance at a strategic level. According to O'Riordan (2017) strategic HRM focuses on the future development of an organization and how this can be supported by HR policies and practices. Any organization that has embraced strategic HRM must ensure that it has a motivated workforce with the appropriate knowledge, abilities and skills. To support this, strategic HRM should be geared towards the support, development and retention of employees.

Bucall and Purcell (2016) have set forth key characteristics of strategic HRM. Some of these characteristics are the use of HRM practices in an integrated manner, employees with their skills and experiences are a considered a key competitive resources, the management is mandated to proactively scan the internal and external environments so as to incorporate the emerging environmental dynamics into the short and long-term goals of the organization. However, Armstrong and Brown (2019) caution that strategic HRM only becomes effective when it provokes strategic behavior on the part of HR managers, employees and the line managers. Strategic HRM should provide the guidelines for implementing HR strategies at the organization and individual level. Bucall and Purcell (2016) reinforce this by stating that strategy in HR is about organization continuity, anticipation of change and the applicability of the strategy considering the circumstances. All these strategic HR components when implemented to provoke overall organizational strategic behavior will lead to organization effectiveness. 
International Journal of Business Management, Entrepreneurship and Innovation, Volume 2, Issue 2, 2020, PP 1-18, ISSN 2707-8027

[IJCAB

\subsection{Adaptive Performance}

Park and Park (2016) define adaptive performance as an employee's anticipatory behavior towards changes affecting assigned job-tasks. Marques-Quenteiro et al (2018) add that adaptive performance in the work place involves behavioral dimensions such as creative problem solving, remaining calm under pressure and handling frustrations effectively. Swiss, Witt and Shoss (2015) on the other hand link adaptive performance to an individual's characteristics such as personality, attitude, self-efficacy and intelligence and can be enhanced through self-leadership training. The business environment of the $21^{\text {st }}$ Century has become so volatile due to the dynamic nature of the operating contexts of different organizations. Organization leaders and their team members are now challenged to work in a reality that is a mix of rapid change and unpredictable events (Marques-Quenteiro et al, 2018). Globalization has changed the work context and this mandates organizations to work with employees who are highly adaptable and have the flexibility to work in unpredictable work situations and adapt to culturally diverse social contexts (Suharti, Handoko and Huruta, 2019).

According to Park and Park (2019) adaptive performance as an HR practice reflects the need to address employee adaptability to the volatile work environment. This is because of the advantages that can be enjoyed by the employee and the employer. At the individual level, adaptive performance can enhance performance and career progression while at the organization level, employees' adaptive performance can lead to successful change management, organization learning and handling the changing customer expectations. Sweet, Witt and Shoss (2015) state that the nature of work is changing due to the rise of self-managed teams, job roles are becoming more fluid and virtual organizations are emerging. There is also constant turbulence around organizations and this underscores the subsequent need for employers to embrace adaptive performance as a human resource practice. Without highly adaptive work behavior, employees may not contribute to organization effectiveness (Marques-Quinteiro et al, 2018). This makes adaptive performance a key component of the bundle of contemporary HRM practices.

\subsection{Psychological Contract}

Psychological contract is the mental perception of the employee's obligations towards the employer as well as the employer's perception of the employee's obligations towards the organization (Maia \& Bastos, 2019). It is an assumed two sided exchange and reciprocity that is not documented but is inferred from one's action and behavior in the organization. An employee shows the fulfilment of the psychological contract by his or her level of identification, commitment and involvement with the organization. This is further displayed in in-role fulfilment and the employee's organization citizenship behavior. At any one time, the state of an employee's psychological contract with the organization has a considerable impact on job performance. It is upon the organization leader to ensure that the employee feels that their psychological contract has been fulfilled as this will enhance their commitment to the organization and their performance (Roussea, Hansen \& Trompou, 2016). This is not easy to manage because it is based on assumptions and perceptions that are at play in the organization context.

According to Agbozo et al (2018) there are two types of psychological contacts; at the top of the list is the transactional contract that is short-term in nature and the employee puts emphasis on the financial or other rewards that they expect to receive after job performance. The other type is relational psychological contract that is built through the socio-emotional and inwardly founded trust that exists between the employee and the employer. An employee who has a relational 
International Journal of Business Management, Entrepreneurship and Innovation, Volume 2, Issue 2, 2020, PP 1-18, ISSN 2707-8027

[IJCAB

psychological contract bases their contract on recognition, work-life balance, room for creativity and career development. It is clear that it is better for organization leaders to strive to have relational psychological contracts with employees and this can be done through the implementation of the most appropriate human resource practices (Chahar, 2019). Some of the HR practices that can help a leader to sustain and minimize the breach of the psychological contract are a favorable working environment and supervisory support (Soomro et al, 2016).

\subsection{Talent management}

Ansar and Baloch (2018) define talent management as the deliberate development and deployment of human resource strategies that enhance the utilization of the organization's talent pool. This helps the organization to ensure that there is a continuous supply of talent to meet its short and long term objectives. In addition to this, the human resource manager ensures that the overall activities of the organization are in harmony with the talent management processes. Talent is a scarce and highly sought after resource and according to Sohel-Uz-Zaman (2018) it is a desirable quality in employees and organizations are always in need of employees with the right talent. Unfortunately, organizations are always competing for these scarce human resources. However, Dahshan, Keshk and Dorgham (2018) caution that the presence of talented employees in an organization does not guarantee success. This is why organization leaders need to invest in the deliberate utilization of the acquired talent and harness this resource for the benefit of the organization. This is what gives life to talent management as an HR practice.

Ansar and Baloch (2018) opine that talent management focuses on key employees who are able to contribute to an organization's strategic objectives and demonstrate high levels of performance. Effective talent management requires a robust policy that highlights processes, instruments for talent identification, development, communication and the retention of talented employees. Beardwell and Thompson (2017) advise that the most important component of talent management is the organization's ability to retain the talented employees and continue to harness their contribution to the organization. This is done by increasing pay, giving competitive benefits and enhancing work-life balance. However, this has to be complemented by having information on why employees leave the organization.

\subsection{Coaching}

Utrilla, Grande and Lorenzo (2015) define coaching as a human resource management practice that equips employees with the knowledge, ability and skills for professional development and enhances their in-role effectiveness. Tompkins (2018) adds that coaching is a structured and continuously monitored process that helps an employee to achieve optimal performance levels. According to Dolot (2017) in the coaching process, it is essential to focus on employee behavior before the process starts and when it is completed. This is because the purpose of coaching is to bring behavioral change. This is reinforced by Skoumpopoulu (2017) who adds that coaching also helps employees to understand how their cognitive and emotional reactions interfere with personal effectiveness, performance and well-being in the work place. Sustained and positive work behavior is the ultimate goal of most coaching engagements. The coach is not supposed to control but to help the employee to develop new capabilities, see new perspectives and create worlds of opportunities.

The justification for coaching in contemporary organizations is that managers, supervisors and team leaders coach team members with the intention of increasing the worth of the organization's 
International Journal of Business Management, Entrepreneurship and Innovation, Volume 2, Issue 2, 2020, PP 1-18, ISSN 2707-8027

\section{IJCAB}

capital. In the process of coaching, the team leader is able to use his or her observational skills to determine team performance and the potential to close that gap by developing the team's full capability. The developed team members can assume some of the team leader's responsibilities and free him or her to work on more visionary projects (Dolot, 2017). Coaching should be inculcated into human resource practices as the benefits for the organization and the employees are significant. Skoumpopoulu (2017) asserts that workplace coaching as a human resource management practice can empower, motivate and enhance the commitment of employees. This will lead to high levels of productivity and self-reliance thereby enhancing organization effectiveness.

\subsection{Organization Effectiveness}

Tahsildari and Shahnaei (2015) contend that most authors view organization effectiveness as a very complex phenomenon. Organizations face pressure from stakeholders, competitors, technological advances and economical challenges. Schuler and Jackson (2014) agree with this assertion and add that organizations must strive to be effective. This effectiveness can only be achieved if employees at all levels of the organization choose actions and make decisions that are geared towards sustaining organizational performance. Some of the components of organization effectiveness are; resource acquisition, goal accomplishment and stakeholder satisfaction (Rahmawati et al, 2016).

\subsection{Goal Accomplishment}

The effectiveness of an organization is gauged by its ability to meet its goals and objectives with optimum input and output. This is not easy because organizations operate in dynamic and highly competitive environments. An effective organization is one that is able to achieve the set goals and objectives. However, Almatrooshi, Singh and Farouk (2016) contend that the achievement of organization goals depends on employee performance together with creating an effective approach to managing human resources, the expertise of a leader and support from the top leadership. These human resource practices should be focused on harnessing the employee skills to develop high quality products. This will ensure that the performance of its employees is an integral part of achieving organizational goals (Bashaer \& Singh, 2016).

An organization cannot be effective without its human resources. Every manager should strive to put in place human resource practices that ensure that employees are involved in strategy execution, can help in improving planning, are experts in the way that work is organized and executed and deliver administrative efficiency that leads to organizational effectiveness and the accomplishment of organizational goals (Mwaniki \& Gathenya, 2015).

\subsection{Stakeholder Satisfaction}

According to Meraku (2017) an effective organization is one that finds a balance between the demands of the board of directors, the stakeholders, the community and the employees. Schuler and Jackson (2014) agrees with this and adds that all these stakeholders have a right to demand that their perspectives are taken into consideration. The aim of an organization is to harness the best performance out of its employees. Rahmawati et al (2016) agrees with this and advise that this can only be done through the implementation of HR practices that foster and retain a highly skilled workforce, ensure that employees perform their tasks to the best of their ability and are highly adaptive to the changing demands of the organization. According to Armstrong and Brown (2019) the very changing work environment mandates employees to be more creative and find 
International Journal of Business Management, Entrepreneurship and Innovation, Volume 2, Issue 2, 2020, PP 1-18, ISSN 2707-8027

[IJCAB

ways of enhancing organization effectiveness. To enhance organization effectiveness, leaders strive for adaptability and a positive work environment.

Organization effectiveness is very important for stakeholders. Ferro-Soto et al (2018) state that stakeholders can be customers, employees, suppliers or entities that interact with an organization and can exert direct or indirect influence on an organization. It is imperative that the HR practices that are implemented in an organization enhance its effectiveness and satisfy or even exceed stakeholder expectations. Ehnert et al (2016) set forth the concept of sustainable human resource management. This is the adoption of HR practices that enable an organization to achieve its "financial, social and ecological goals, with an impact inside and outside the organization and over a long-term horizon while controlling the unintended side effects and negative feedback" (Ehnert et al, 2016 p. 90). From this excerpt, organizations should endeavor to embrace HR practices that enhance their effectiveness and at the same time positively influence relationships with stakeholders so as to enhance organization sustainability and effectiveness.

\subsection{Resource Acquisition}

Organizations use acquired resources to work towards effectiveness. According to Mwai et al (2018) resources are "tangible and intangible assets that a firm uses to choose and implement its strategies" (p. 1636). An organization may have highly qualified employees and financial resources for strategy implementation but poor or archaic human resource management practices can be a major obstacle. This will lead to organization failure because HR practices play a major role in the implementation of an organizations' strategy (Alami et al, 2015). Rahmawati et al (2016) contend that resources provide the organization with the means to innovate, exploit opportunities, sustain competitive advantage and satisfy stakeholder needs. Ombaka et al (2015) adds that organization processes and human resource management practices are moderated to a great extent by their resources. According to Eydi (2015) organization leaders strive to exploit the environment for the acquisition of scarce and valued resources. At the same time, the organization has to continuously attract resources to enhance its viability and sustainability. Based on this, an organization is considered effective if it is able to obtain significant resources that it can use for the effective implementation of its strategies (Mwai et al, 2018). The above authors are emphasizing that resource acquisition and exploitation using contemporary human resource management practices is necessary for organization effectiveness. 
International Journal of Business Management, Entrepreneurship and Innovation, Volume 2, Issue 2, 2020, PP 1-18, ISSN 2707-8027

[iJCAB

\section{Conceptual Framework}

Employee Human

Characteristics

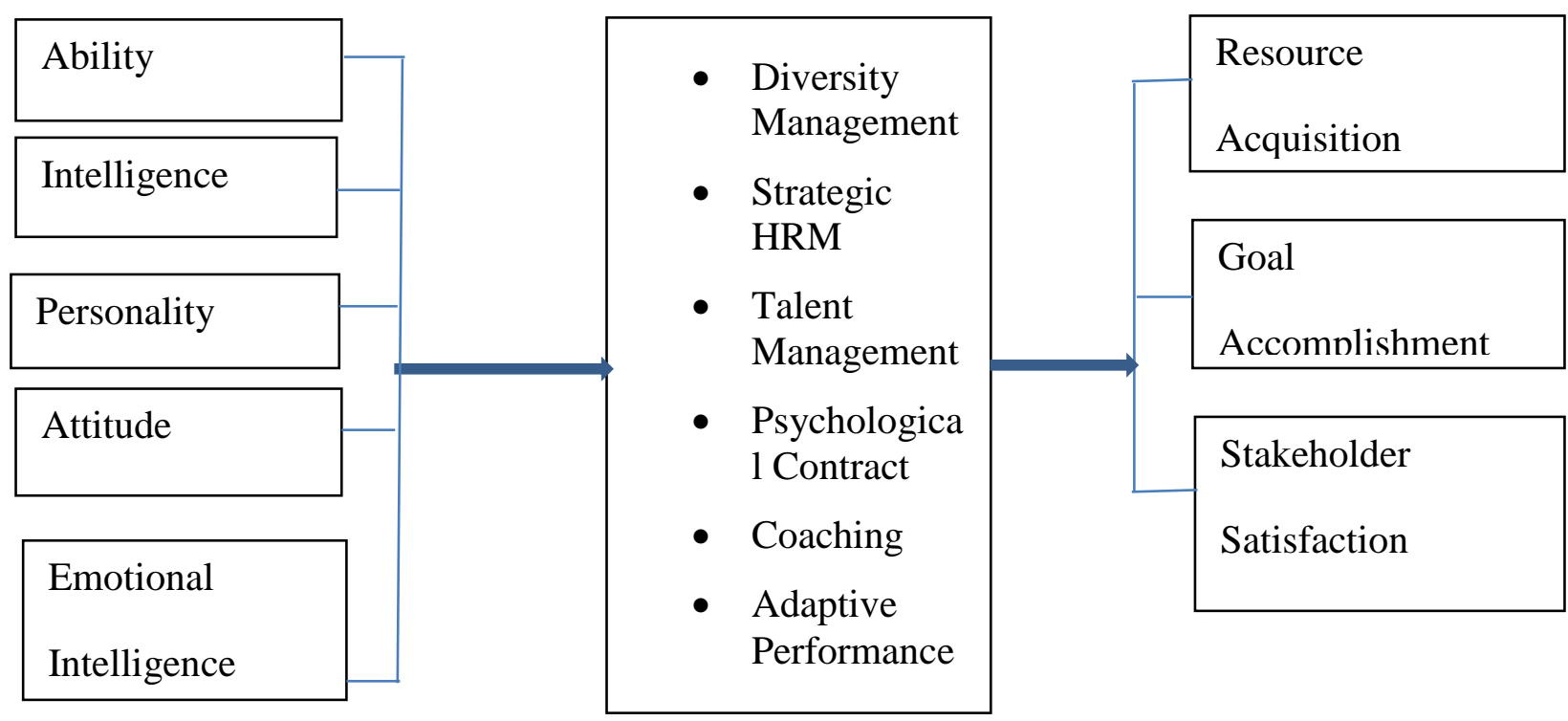

On the above conceptual framework, the independent variables are the employee characteristics. The intervening variables are the human resource management practice components. The dependent variable are the indicators of organization effectiveness. Employee characteristics and human resource management practices have an impact on the effectiveness of an organization as depicted in the conceptual framework According to Mehmood et al (2017) the effectiveness of the most talented employees will be less if measures are not put into place by organization to motivate employees to perform. This mandates organization leaders to implement contemporary human resource management practices that impact on organization effectiveness. Employee characteristics are very important because what an employee achieves in an organization is to a very large extent shaped by his or her habits and attitudes that make up the character.

Organization leaders should proactively evaluate the employee character and attributes and make use of them in enhancing organization effectiveness. This is because character transcends culture, organization structures and employee levels of education (Chowdhury, 2016). The business world is constantly changing in terms of diversity and new opportunities. This underscores the need for organizations to retain highly skilled employees. One way of ensuring that the organization has a pool of skilled employees is through the use of coaching as an HR practice. Organizations that have embraced the culture of coaching have reaped the benefits of improved performance and their employees feel valued. This enhances employee retention. (Tompkins, 2018). According to Wadhwa and Madan (2017) organizations gain competitive advantage because of a stable and committed workforce. Utrilla et al (2015) add that the capabilities and knowledge that is gained by employees during coaching helps an organization to develop and use resources that enhance its effectiveness.

Nzitunga and Nyanway-Gimeh (2016) opine that as the work environment becomes more turbulent and unpredictable, organizations need employees who have high levels of adaptability so that they 
International Journal of Business Management, Entrepreneurship and Innovation, Volume 2, Issue 2, 2020, PP 1-18, ISSN 2707-8027

1JCAB

are able to cope with diverse cultures, client demands, face new problems and adapt to the ever changing technology. Organization leaders have to train employees to enhance their adaptive performance capabilities. Without this, organization effectiveness is compromised. According to Marques-Quinteiro et al (2018) adaptive performance can be enhanced in employees through selfleadership training. Sesen and Tabak (2017) define self-leadership as the way that an individual controls his or her behaviors, influences others and effectively leads self with calculated behavioral and cognitive strategies. Employee training in self-leadership to enhance adaptive performance is a very important human resource management practice. This is because being able to perform adaptively in an organization setting is a prerequisite for sustainability and organization effectiveness. Rees and Smith (2017) point out that employees who have the cognitive and behavioral competencies to adapt to the complex work situations find themselves being considered as core employees while employees who are not able to display adaptive performance face the prospect of being sacked. It is very important for employees to be highly adaptive.

According to Mondy and Martocchio (2016) talent management is a key human resource management practice as it is the integration of performance management, succession planning, employee retention, recruitment, development and compensation. It is imperative for organization leaders to have a fully integrated talent management practice that ensures that the organization has employees with the right talent to lead and sustain strategic objectives. Dahshan et al, 2018 advise that a proactive talent management system continuously analyzes the human resource function, organization goals, competitors, systems and processes. Doing this helps the organization to promote workforce productivity leading to organization effectiveness. Talent management is a key contributor to organization effectiveness because the dynamic environment provides the contemporary human resource manager with a significant challenge.

Kirton and Greene (2018) contend that there are common instances of stereotype underpinning especially in international organizations in the form of subtle race discriminations. These underpinnings end up reproducing glaring inequalities in the form of concrete ceilings and different ethnic groups are ascribed cultural traits that condemn them and negatively impact on perceptions of their ability to do certain jobs. Management has to be on the lookout for such negative workplace practices as they may impede organization effectiveness and in some instances if encouraged, will inform recruitment decisions and the allocation of jobs to individuals regardless of their talents, knowledge and ability. Fapohunda (2017) advises that workplace diversity will subsist. It is upon the HR and the line managers to embrace diversity management as an HR practice by valuing diversity and treating each employee as a unique entity who has to be supported, accepted, his or her disparities appreciated so as to maximize workforce productivity and achieve organizational effectiveness.

According to Rees and Smith (2017) the psychological contract is very important as it is what mediates the relationship between organizational policies, work context, supervision and employee work outcomes like commitment and job satisfaction. Zupan et al (2018) report that human resource managers are having challenges retaining millennials in organizations. These managers need to use the implied psychological contracts to manage millennial expectations regarding the employment relationship. The management should ensure that the psychological contract is not breached and should be able to gauge and anticipate to a large extent the employee attitude, job satisfaction and turnover intentions. This will help in enhancing organization effectiveness. Yarbrough (2015) cautions that the psychological contract is a philosophy and not a tool and this makes it a very complex employer-employee relationship. As a human resource management 
International Journal of Business Management, Entrepreneurship and Innovation, Volume 2, Issue 2, 2020, PP 1-18, ISSN 2707-8027

[IJCAB

practice, acknowledging the psychological contract entails recognition of the employee perceptions and understanding the significant benefits that the organization stands to gain from fostering and supporting psychological contracts (Maia \& Bastos, 2019).

According to Noe et al (2019) strategic HRM is a very important component of the human resource management practice because it supports business strategy. The HRM does this by engaging in proactive human resource planning, organization development and change management (Selam, 2016). According to Hamadamin and Atan (2019) strategic human resource management also involves human capital development so that the employees have the requisite skills and knowledge that are important in a competitive business environment. This will also lead to organization effectiveness as the employees will be more effective and efficient as they perform their assigned tasks. Armstrong and Brown (2019) caution that strategic HRM must have a strategic organizational fit. This is because decisions made must be in tandem with the prevailing circumstances in the organization. At the same time, the human resource manager has to lead the organization members in appreciating the factors that will affect the future strategic direction to be taken.

Organizations have different levels of stress, working hours and complex work processes. All these impact on employees in different ways depending on individual characteristics. Studying employee characteristics as a human resource management practice is a necessity for organization leaders as this is what interprets into employee commitment and involvement towards the organization (Rahiman \& Kodikal, 2017). According to Duckworth and Yeager (2015) organization leaders work with many employees with unique personalities. It is important for the organization to have a deep understanding of these unique personalities because if an employee possesses the appropriate personality traits, he or she will be able to accomplish the assigned tasks within the agreed timelines and contribute to organizational effectiveness. Gupta and Gupta (2019) support this by stating that employees who possess high conscientiousness as a personality trait are very important in an organization as they are organized, disciplined, orderly and hard working. It is up to the organization leader to make use of such an employee by giving them job roles that tap into their conscientiousness. There are job roles that are challenging, hectic with heavy workloads and insensitive supervisors. This leads to employee psychological distress, emotional outbursts and burnout. Organization leaders should ensure that employees are continuously trained on emotional intelligence so that they are skilled at regulating their emotions and communicating effectively as they perform their tasks. This human resource practice will go a long way in enhancing employee performance and organization effectiveness (Mohamad \& Jais, 2017).

\section{Conclusion and Recommendations}

Organizations are constantly striving for better results and competitive advantage in the turbulent business environment. A key measure of organizational performance is its effectiveness. To attain optimum effectiveness, organizations need to have employees who have the right characteristics and are trained with the right knowledge, abilities and skills. These employees need to be managed in such a way that they stay motivated and committed to creatively achieve the organizational goals. Employee characteristics and human resource management practices support organization effectiveness. The organization leaders have to study employee characteristics and ensure that this is taken into account as employees are assigned job roles. An effective organization is characterized by its ability to obtain significant resources that it can use for the effective 
International Journal of Business Management, Entrepreneurship and Innovation, Volume 2, Issue 2, 2020, PP 1-18, ISSN 2707-8027

[IJCAB

implementation of its strategies. Such an organization must also be able to achieve its financial, social and ecological goals while continuously evaluating its impact on its internal and external environment.

\section{REFERENCES}

Abubakar, G.S., Dogoji, A.B. and Yahay, M.L. (2015). New Dimension of Human Resource Development: The Inclusiveness of IQ, EQ and SQ Elements in Constructing Human Development Program. An Evaluation of some selected Organizations in Bauchi Metropolis, Bauchi State, Nigeria. International Journal of Economics and Business Management, $\quad$ 1(8).

Agzobo, K.G., Ansa-Bonnah, E., Hoedoafia, A.M. and Atakorah, B.W. (2018). The Role Psychological Contract Plays in Organizational Behavior: A Case Study of a Public University in Ghana. European Scientific Journal, 14(23).

Alami, R., Sohaei, R., Berneti, M.K.A. and Younesi, A. (2015). The Effectiveness of Human Resource Management in Improving the Performance of Education Staff. International Journal of Business and Social Science, 6(5).

Almatrooshi, B., Singh, K.S. and Farouk, S. (2016). Determinants of Organization Performance: a proposed framework. International Journal of Productivity and Performance Management, 65(6).

Ansar, N. and Baloch, A, (2018). Talent and Talent Management: Definition and Issues. IBT $\begin{array}{llll}\text { Journal of Business } & \text { Studies, }\end{array}$

Arati, S.K. and Suhartini (2017). Impact of Individual, Job and Organizational Characteristics on Organizational Commitment with Job Satisfaction as Intervening Variable. Review of Integrative Business and Economics Research, 6(1).

Armstrong, M. (2009). Armstrong's Handbook of Human Resource Practice. $11^{\text {th }}$ Edition. Kogan Page.

London.

Armstrong, M. and Brown, D. (2019). Strategic Human Resource Management: Back to the Future? A Literature Review. Institute of Employment Studies, 517.

Atristain-Suarez, C. (2016). Best Management Practices: SME's Organizational Performance Management Based on Internal Controls in Mexico. Journal of International Business and Economics,

$4(2)$.

Barak, M.E.M. (2017). Managing Diversity. Towards a Globally Inclusive Workforce. $4^{\text {th }} \quad$ Edition. Sage. $\quad$ California.

Bashaer, A. and Singh, S. (2016). Determinants of Organization Performance: A Proposed Framework. International Journal of Productivity and Performance Management, 65(6).

Beardwell, J. and Thompson, A. (2017). Human Resource Management: A Contemporary Approach. $\quad 8^{\text {th }}$ Edition. Pearson Education Limited. UK.

Boe, O. and Bang, H. (2017). The Big 12: The Most Important Character Strengths for Military Officers. Athens Journal of Social Sciences, 4(2).

Boxall, P. and Purcell, J. (2016). Strategy and Human Resource Management. Palgrave Macmillan.

London.

Chahar, B. (2019). Psychological Contract and Organization Citizenship Behavior. Exploring the Interrelatedness Through Cross Validation. Academy of Strategic Management Journal,

$18(1)$.

Chowdhury, M. (2016). Emphasizing Morals, Values, Ethics, and Character Education in 
International Journal of Business Management, Entrepreneurship and Innovation, Volume 2, Issue 2, 2020, PP 1-18, ISSN 2707-8027

[IJCAB

Science Education and Science Teaching. The Malaysian Online Journal of Educational Science, 4(2).

Cross, C. and Carbery, R. (2016). Organizational Behavior. An Introduction. Palgrave Macmillan Education.

London.

Dahshan, A.E.M., Keshk, I.L. and Dorgham, S.L. (2018). Talent Management and Its Effect on Organization Performance among Nurses at Shebin El-Kom Hospitals. International Journal of Nursing, 5(2).

Dolot, A. (2017). Coaching Process and Its Influence on Employees' Competencies in the Hospitality Sector - Case Study. International Journal of Contemporary Management, 16(2).

Drigas, S.A. and Papoutsi, C. (2018). A New Layered Model on Emotional Intelligence. Behavioral

Sciences.

Duckworth, A.L and Yeager, D.S. (2015). Measurement Matters: Assessing Personal Qualities other than Cognitive Ability for Educational Purposes. Research in Education, 44(4).

D'Souza, F.Z. and Poojary, S. (2018). Employee Attitude towards Organizational Commitment: A Literature Survey. IOSR Journal of Business and Management, 20(1).

Ehnert, I., Parsa, S., Roper, I, Wagner, M. and Muller-Camen, M. (2016). Reporting on Sustainability and HRM: a comparative study of sustainability reporting practices by the world's largest companies. The International Journal of Human Resource Management, 27.

Eydi, H. (2015). Organizational Effectiveness Models: Review and Application to Non-Profit Sporting Organizations. American Journal of Economics, Finance and Management, 1(5).

Fapohunda, T. (2016). Workplace Diversity Management: A Corporate Performance Driver. International Journal for Research in Business, Management and Accounting, 2(1).

Ferro-Soto, C., Marcias-Quintana, A.L. and Vasquez-Rodriguez, P. (2018). Effect of Stakeholder Oriented Behavior on the Performance of Sustainable Business. Sustainability,

10(4724).

Gupta, N. and Gupta, A.K. (2020). Big Five Personality Traits and Their Impact on Job Performance of Managers in the FMCG Sector. International Journal of Recent Technology and Engineering, 8(5).

Hamadamin, H.H. and Atan, T. (2019). The Impact of Strategic Human Resource Management Practices on Competitive Advantage Sustainability: The Mediation of Human Capital Development and Employee Commitment. Sustainability, 11(5782).

Heath, K., Martin, L. and Shahisaman, L. (2017). Global Leadership Competence: The Intelligence Quotient of a Modern Leader. Journal of Leadership Education.

Higgs, M. and Dulewicz, V. (2016). Leading with Emotional Intelligence. Effective Change Implementation in Today's Complex Context. Palgrave Macmillan. Switzerland.

Hirasawaa, J. (2106). Hiring New Graduates in Japan and "Character". Repositioning, 1(10).

Kannaiah, D. and Shanthi, R. (2015). A Study of Emotional Intelligence at the Work Place. European Journal of Business and Management, 7(24).

Kanwal, E., Nawaz, W., Nisar, Q. and Azeem, M. (2017). Does Organization Learning Capacity Influence the Organization Effectiveness? Moderating Role of Absorptive Capacity. International Journal of Engineering and Information Systems, 1(7).

Kirton, G. and Greene, A. (2016). The Dynamics of Managing Diversity. A critical approach. $4^{\text {th }}$ Edition. Routledge. Taylor and Francis. London. 
International Journal of Business Management, Entrepreneurship and Innovation, Volume 2, Issue 2, 2020, PP 1-18, ISSN 2707-8027

[IJCAB

Leutner, F. and Chamorro-Premuzic, T. (2018). Stronger Together: Personality, Intelligence and the Assessment of Career Potential. Journal of Intelligence.

Mahmood, A., Arshad, A.M., Ahmed, A., Akhtar, S. and Rafique, Z. (2015). Establishing Linkages between Intelligence, Emotional and Spiritual Quotient on Employee Performance in Government Sector of Pakistan. Mediterranean Journal of Social Sciences,

6(6).

Maia, G.L. and Bastos, B.V.A. (2019). Climbing the Ladder of Performance: Are Psychological Contracts Organization Commitment Steps? Brazilian Administration Review.

Manik, E. and Sidharta, I. (2017). The Impact of Motivation, Ability, Role Perception on Employee Performance and Situational Factor as Moderating Variable of Public Sector in Bandung, Indonesia. International Journal of Management Science and Business Administration,

$3(4)$.

Marques-Quinteiro, P., Eiffer, N., Vargas, R. and Curral, A.L. (2018). Employee Adaptive Performance and Job Satisfaction during Organization Crisis: the role of self-leadership. European Journal of Work and Organization Psychology.

Marwaha, S. (2015). Analysis of Emotional Quotient and Intelligence Quotient among High Achievers and Low Performers in School Academics. International Journal of Home Science,

l(2).

McShane, L.S. and Von Glinow, A.M. (2018). Organizational Behavior. $8^{\text {th }}$ Edition. McGraw Hill Education. New York.

Mehmood, M., Awais, M., Afzal, M.M., Shahzadi, I. and Khalid, U. (2017). Impact of Human Resource Management Practices on Organizational Performance. International Journal of Engineering and Information

Meraku, A. (2017). The Role of Leadership in Organization Effectiveness. Journal of Economics, Business and Management, 5(11).

Mohamad, M. and Jais, J. (2016). Emotional Intelligence and Job Performance: A Study Among Malaysian Teachers. Procedia Economics and Finance.

Mondy, W.R. and Martocchio, J.J. (2016). Human Resource Management. $14^{\text {th }}$ Edition. Pearson Education Limited. England.

Mwai, G.M., Namada, M.J. and Katuse, P. (2018). Influence of Organizational Resources on Organizational Effectiveness. American Journal of Industrial and Business Management,

8.

Mwaniki, R. and Gathenya, J. (2016). Role of HR functions on Organization Performance with Reference to Kenya Power and Lighting Company - Nairobi West Region. International Journal of Academic Research in Business and Social Sciences, 5(4).

Najam-us-Sahar, N. (2016). Impact of Personality Type on Job Productivity. Journal of Hotel and Business Management, 5:1.

Noe, A.R., Hollenbeck, R.J., Gerhat, B., Wright, M.P. and Eligh, L. (2016). Strategic Human Resource Management. Gaining a Competitive Advantage. McGraw Hill Education. Canada.

Nuckcheddy, A. (2018). The effect of personality on motivation and organization behavior. Psychology and Behavioral Science. International Journal.

Nzitunga, B.J. and Nyanway-Gimeh, M.C. (2016). Effect of Cross-Cultural Competencies on Adaptive Performance among United Nations Peacebuilding Practitioners. Business, Management and Economics Research, 2(3).

Nzuve, N.M.S. and Njambi, P.W. (2015). Factors Perceived to Influence Employee 
International Journal of Business Management, Entrepreneurship and Innovation, Volume 2, Issue 2, 2020, PP 1-18, ISSN 2707-8027

[IJCAB

Performance: A Case of the Independent Electoral and Boundaries Commission. Problems of Management in the $21^{\text {st }}$ Century, 10(2).

Ombaka, B., Machuki, V.N. and Mahasi, J. (2015). Organizational Resources, External Environment, Innovation and Firm Performance: A Critical Review of Literature. $D B A$ Africa Management Review, 5(1).

O'Riordan, J. (2017). The Practice of Human Resource Management. State of the Public Series. Institute of Public Administration.

Osborne, S. and Hammoud, S.M. (2017). Effective Employee Engagement in the Workplace. International Journal of Applied Management and Technology, 16(1).

Park, S. and Park, S. (2019). Employee Adaptive Performance and Its Antecedents: Review and Synthesis. Human Resource Development Review, 18(3).

Pradhan, K.R. and Jena, K.L. (2017). Employee Performance at the Workplace: Conceptual Model and Empirical Validation. Business Perspective and Research, 5(1).

Rahiman, U.H. and Kodikal, R. (2017). Impact of Employee Work Related Attitudes on Job Performance. British Journal of Economics, Finance and Management Sciences, 13(2).

Rahmawati, A., Haerani, S., Taba, I.M. and Hamid, N. (2016). Measures of Organization Effectiveness: Public Sector Performance. IRA - International Journal of Management and Social Sciences, 5(2).

Rees, G. and Smith, E.P. (2017). Strategic Human Resource Management. An International Perspective. $2^{\text {nd }}$ Edition. Sage. London.

Rousseau, M.D., Hansen, D.S. and Tomprou, M. (2016). A Dynamic Phase Model of Psychological Contract Processes. Journal of Organization Behavior.

Selam, T. (2016). Talent Management: A Review of Theoretical Perspectives and Guidelines for Practitioners. Nile Journal of Business and Economics, 4.

Sesen, H. and Tabak, A. (2017). Consequences of Self-Leadership: A Study on Primary School Teachers. Educational Sciences Theory and Practice, 17(3).

Sharma, J. and Dhar, L.R. (2016). Factors Influencing job performance of nursing staff. Personnel Review,

$45(1)$

Sherman, R.A., Rutherman, J.F., Serfass, D.G. and Jones, A.B. (2015). The independent effects of personality and situations on real-time expressions of behavior and emotion. Journal of Personality and Social Psychology, 109(5).

Schuler, S.R. and Jackson, E.S. (2014). Human Resource Management and Organizational Effectiveness: Yesterday and Today. Journal of Organization Effectiveness: People and Performance, 1(1).

Siddiqi, H. (2016). The Impact of Employee Creativity on the Performance of a Firm. Research Issues in Social Sciences, I.

Skoumpopoulu, D. (2017). Understanding Good Practice in Workplace Coaching. Frontiers in Management

Research,

$1(2)$.

Sohel-Uz-Zaman, M.S.A. (2018). Understanding the Fundamentals of Talent Management for Effective Business Application. International Journal of Economics, Finance and Management Sciences, 6(3).

Soomro, A.F., Syed, S. and Memon, B.S. (2016). Exploring the Contents of Psychological Contract: The Employees' Perspective of the Hospitality Industry in Upper Sindh. International Journal of Academic Research in Business and Social Sciences, 6(3).

Subramanian, K.R. (2016). Employee Attitudes and Employment Dilemma. International Journal of Combined Research and Development, 5(9). 
International Journal of Business Management, Entrepreneurship and Innovation, Volume 2, Issue 2, 2020, PP 1-18, ISSN 2707-8027

iJCAB

Suharti, L., Handoko, A.Y and Huruta, D.A. (2019). Linking Cultural Intelligence and Adaptive Performance: Do Intercultural Interactions and Host University Support Play Important Roles? Business, Management and Education.

Sweet, M.K., Witt, A.L. and Shoss, K.M. (2015). The Interactive Effect of Leader-Member Exchange and Perceived Organization Support on Employee Adaptive Performance. Journal of Organization Psychology, 15(1).

Triana, M. (2017). Managing Diversity in Organizations. A Global Perspective. Taylor \& Francis. $\quad$ London.

Tahsildari, A. and Shahnaei, S. (2015). Enhancing Organizational Effectiveness by Performance Appraisal, Training, Employee Participation, and Job Definition. European Journal of Business and Management. Vol, 7, No, 12.

Tompkins, W.M. (2018). Coaching in the Workplace. Journal of Practical Consulting, 6(1).

Tripathy, N. (2018). Emotional Intelligence: An Overview. Lambert Academic Publishing. Mauritius.

Utrilla, C.N.P., Grande, A.F. and Lorenzo, D. (2015). The effects of coaching on employee and organization performance: The Spanish Case. Intangible Capital, 11(2).

Wadhwa, S. and Madan, S. (2017). Employee Retention: A Much Needed Strategy in Global Work Environment. International Journal of Engineering and Management Research, 7(4).

Waheed, A., Miao, X., Waheed, S., Ahmad, N. and Majeed, A. (2019). How new HRM Practices, Organizational Innovation and Innovative Climate affect the Innovation Performance in the IT Industry: A Moderated-Mediation Analysis. Sustainability, 11(621).

Yarbrough, R.J. (2015). Understanding the Importance of Employee/Employer Psychological Contract. Journal of Management and Marketing Research, 21. Youshan, B.B. and Hassan, Z. (2015). The effect of employee personality on organization performance: A study on insurance companies. International Journal of Accounting and Business

Management,

$3(1)$.

Zupan, N., Mihelic, K.K. and Aleksic, D. (2018). Knowing me is the Key: Implications of Anticipatory Psychological Contract for Millenials' Retention. Psychology of Retention: Theory, Research and Practice.

This is an open-access article published and distributed under the terms and conditions of (cc) (†) \&

the Creative Commons Attribution 4.0 International License of United States unless otherwise stated. Access, citation and distribution of this article is allowed with full recognition of the authors and the source.

Authors seeking to publish with an Internationally Peer Reviewed Journals should consider https://www.ijcab.org/ by writing to the Editor at editor@ijicab.org or submitting online at https://journals.ijcab.org/journals/index.php. The articles must be quality and meet originality test. 